Int. J. Dev. Biol. 61: 397-405 (2017)

doi: $10.1387 / \mathrm{ijdb} .160360 \mathrm{et}$

\title{
Migration behavior of PGCs and asymmetrical gonad formation in pond smelt Hypomesus nipponensis
}

\author{
EISUKE TAKAHASHI*,1,2, YU SHIMIZU1,2, HIROTARO URUSHIBATA ${ }^{1,2}$, YUTAKA KAWAKAMI', \\ KATSUTOSHI ARAI ${ }^{2}$ and ETSURO YAMAHA ${ }^{1}$ \\ ${ }^{1}$ Nanae Fresh-Water Station, Field Science Center for Northern Biosphere, Hokkaido University and ${ }^{2}$ Laboratory of Aquaculture \\ Genetics and Genomics, Faculty and Graduate School of Fisheries Sciences, Hokkaido University, Hokkaido, Japan
}

\begin{abstract}
In teleost fish, the gonad originates from primordial germ cells (PGCs) and somatic cells. However, it is not clear whether the final gonadal position is determined by anteroposterior and dextrosinistral differentiation of endodermal organs or by the distribution of PGCs. The pond smelt has a transparent body even after hatching, enabling clear observation of PGC distribution and endodermal differentiation. Here, we first examined normal embryonic development to define the spatio-temporal characteristics of our developmental model. Second, the origin of PGCs was investigated by in situ hybridization. Third, the migration route of PGCs was tracked by microinjection of GFP-nos3 3' UTR mRNA and visualization of PGCs by green fluorescent protein. Lastly, differentiation of gonadal and endodermal organs was examined histologically. Maternal vasa transcripts were detected at the ends of cleavage furrows, indicating that PGCs differentiated by inheritance of germplasm as in other teleosts. During gastrulation, PGCs migrated following somatic cell movement and lined both sides of the embryonic body. During the segmentation period, PGCs moved posteriorly and were distributed in a line among dorsal mesentery cells around the posterior part of the intestinal bulb in the $16^{\text {th }}$ to $24^{\text {th }}$ somite region at 3 days post hatching. At 1 month post hatching, the gonad was formed at the $20^{\text {th }}$ somite region. PGC distribution was biased to the left side of the body cavity, while the pancreas was formed on the right side. These results indicate that PGCs accumulate at the gonadal region by dorsal mesentery cells, and gonadal position is determined by the digestive system.
\end{abstract}

KEY WORDS: primordial germ cell, $P G C$, cell lineage, asymmetrical gonad formation, cell migration, pond smelt

\section{Introduction}

The gonad is formed by germ cells and somatic cells. Germ-line cells differentiate by inheritance of maternal factors, or induced by inter-cellular interactions during development at a distant body site. Committed germ cells are called primordial germ cells (PGCs) and have been found in almost all metazoans from Porifera to Mammalia (Extavour and Akam, 2003). PGCs can migrate long distances from their origin to the genital ridge (Molyneaux and Wylie, 2004). It has been suggested that the presumptive gonadal area is induced in the dorsal mesentery during development and that it differentiates into the gonad by inclusion of germ and somatic cells (Nakamura et al., 2006).

The first study on PGCs in bony fishes was performed by Ei- genmann (1891) who investigated the mechanism of ovoviviparous reproduction in shiner perch, and identified PGCs as relatively large, round cells. However, the origin of the PGCs could not be traced before the gastrula stage using the available histological methods. More recently, evolutionary developmental biological approaches have been used to track the origin of PGCs in bony fishes. The identification of the vasagene, which shows conserved expression in germ cells, has enabled the identification of the developmental origin of PGCs (Yoon et al., 1997). In zebrafish, PGCs differentiate from blastomeres that inherit germ plasm, which is maternally

Abbreviations used in this paper: dpf, days post fertilization; dph, days post hatching; gfp, green fluorescent protein; hpf, hours post fertilization; mph, month post hatching; $\mathrm{PGC}$, primordial germ cell.

\footnotetext{
*Address correspondence to: Eisuke Takahashi. Nanae Fresh-Water Station, Field Science Center for Northern Biosphere, Hokkaido University. 2-9-1, Sakura, Nanae, Kameda, Hokkaido, 041-1105, Japan. Fax: +81-138-65-2239. Tel: +81-138-65-2344 E-mail: e.takahashi0201 @fsc.hokudai.ac.jp web: http://www.fsc.hokudai.ac.jp/nanae/home\%20-\%20english.html - (iD http://orcid.org/0000-0002-1379-7843
}

Supplementary Material (7 figures +1 table) for this paper is available at: http://dx.doi.org/10.1387/ijdb.160360et

Submitted: 5 October, 2016. Accepted: 24 January, 2017. Edited by: Massimo De Felici

ISSN: Online 1696-3547, Print 0214-6282

(C) 2017 UPV/EHU Press

Printed in Spain 
synthesized in advance, and that colonize the cleavage furrow after fertilization. PGCs migrate to the genital ridge and differentiate into the gonad together with somatic cells. In recent years, the origin and migration route has been identified using live cell imaging of GFP marked cells. PGCs can be visualized in real time by microinjection of GFP-conjugated zebrafish nos33'UTR mRNA, an artificially synthesized mRNA, into fertilized eggs (Saito et al., 2006). This technology has been applied to a wide range of species, from archaic fish species such as sturgeon (Saito et al., 2014) to more highly evolved species such as flounder (Goto et al., 2015).

With this new approach, the migratory behavior of PGCs has been characterized in a variety of fish species. PGCs are derived from the cleavage furrow in all analyzed teleosts, then migrate to the lateral side of the embryonic body during gastrulation, and finally to the genital ridge. Three broad types of migratory behavior have been observed during gastrulation (Fig. 1). In the first type, PGCs migrate passively guided by somatic cell movement, mainly conversion, during gastrulation, and localize along the lateral sides of the embryonic body; the PGCs then migrate to the genital ridge on their own. In the second type, PGCs migrate to the lateral sides of the embryonic body through the equatorial plane region during gastrulation, and localize in a small area. In the third type, PGCs migrate to the lateral side of the embryonic body through the animal region of the blastodisc during the blastula and gastrula stages and localize in a small area. The migratory route taken by PGCs differs among species and is not related to the taxonomic position of the species. To date, studies on PGCs migration have been carried out in archaic species or highly evolved species. In order to obtain a more complete understanding of PGCs migration in bony fishes throughout evolution, studies on intermediate species such as pond smelt are required.

After the arrival of PGCs at the presumptive gonadal anlage, the gonad differentiates and produces gametes by interactions between germ cells and somatic cells. In loach and goldfish, it has been reported that sex differentiation can occur without PGCs (Fujimoto et al., 2010; Goto et al., 2012). When this occurs, the fish are sterile although their gonadal somatic cells show the same features as fertile gonads along the anteroposterior axis. Gonadal growth likely depends on the distribution of PGCs, and/or on the surrounding organs, such as stomach, intestine, liver, or swim bladder. However, it is not clear if all PGCs that arrive at the presumptive gonad commit to make gonad or if PGCs are indispensable for

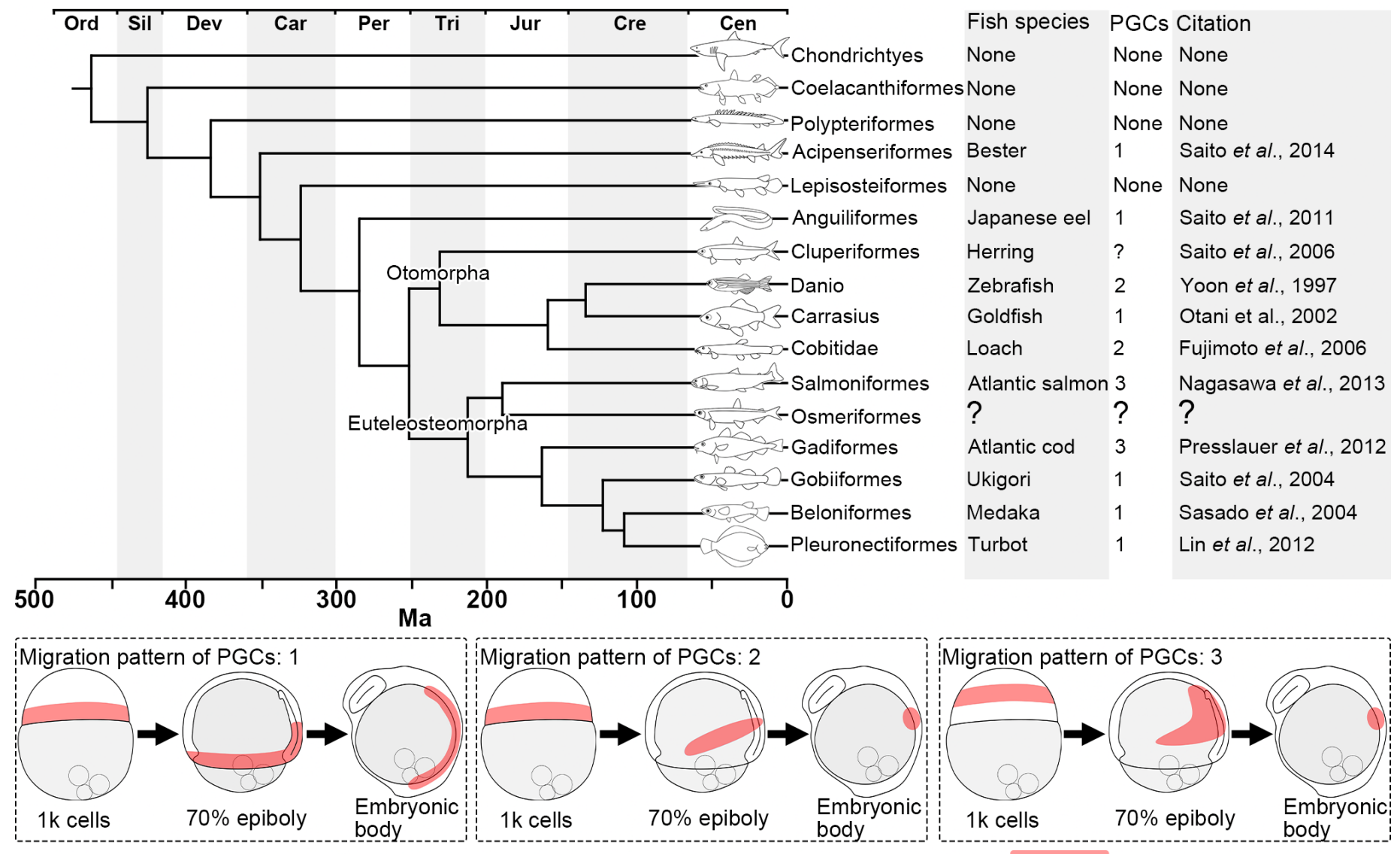

Distributional area of PGCs

Fig. 1. Phylogenetic tree of fishes and migration behavior of primordial germ cells (PGCs) in each species. Phylogenetic tree of fish species (modified from Betancur et al., 2013 and Nakatani et al., 2011). The migration patterns of PGCs in fish species can be classified into three types: (Pattern 1) PGCs are distributed around the lower part of blastodisc at the $1 \mathrm{k}$-cell stage. During gastrulation, PGCs migrate passively with somatic cells and are distributed widely along the embryonic body. (Pattern 2) PGCs are distributed around the lower part of the blastodisc at the $1 \mathrm{k}$-cell stage. During gastrulation, PGCs migrate actively to a restricted region of the embryonic body. (Pattern 3) PGCs are distributed around the middle region of the blastodisc. During gastrulation, PGCs migrate to a restricted region of the embryonic body through the animal-pole region of the blastodisc. 
gonadal differentiation and growth.

Pond smelt (Hypomesus nipponensis, subcohort Euteleosteomorpha, superorder Protacanthopterygii, order Osmeriformes) is an intermediate bony fish between archaic and highly evolved species (Betancur et al., 2013; Fig. 1). Embryological studies have indicated that the pattern of embryonic development in pond smelt is similar to that in highly evolved fishes (Yamada, 1963). In addition, pond smelt has a transparent body even after hatching, enabling clear observation of endodermal differentiation. However, description of embryonic development is still inconclusive and fragmentary. And the migratory behavior of PGCs has not been investigated. The gonads of osmeriform fishes show asymmetric differentiation, with the left gonad being larger than the right (Supplementary Fig. $\mathrm{S1}$ ). It is not clear whether this characteristic depends on the original distribution of PGCs in the genital ridge or on interactions between the gonad and endodermal organs, e.g. liver, pancreas and intestinal tract. These characteristics make pond smelt a valuable model to investigate the interaction between PGCs and endodermal organs during gonadal development in teleosts. In this study, we characterize embryonic development in the pond smelt and investigate PGCs differentiation and migration to the gonadal anlage and how the subsequent gonad differentiation is shaped by surrounding endodermal organs. These analyses provide insights into the influence of surrounding endodermal organs on gonad differentiation.

\section{Results}

\section{Embryonic development of pond smelt at $10^{\circ} \mathrm{C}$}

The first study on embryonic development in pond smelt was carried out by Yamada (1963). However, as this study did not use dechorionation, a detailed description of the formation of the embryonic body, somites and digestive system was not provided. As this information is essential to understand the migratory behavior of PGCs and gonad formation, we examined normal embryonic development in pond smelt with dechorionated embryos. Developmental stages were assigned on the basis of morphological features using the zebrafish model (Kimmel et al., 1995). Here we summarize formation process of the embryonic body and the digestive system. Detailed descriptions are provided in Supplementary Fig. S2 to S5 and Supplementary Table S1.

\section{Formation of the embryonic body}

At 50 hours post fertilization (hpf), the blastodisc covered half of the yolk and an embryonic shield and germ ring had formed (Supplementary Fig. S2 U), coinciding with a 2 h arrest of epiboly. At $64 \mathrm{hpf}$, when epiboly was $90 \%$ complete, cells of both the epiblast and hypoblast began migrating dorsally, leading to the formation of the embryonic body by 72 hpf (Supplementary Fig. S2 W,X). At $84 \mathrm{hpf}$ the embryonic body increased in size and the tail bud was

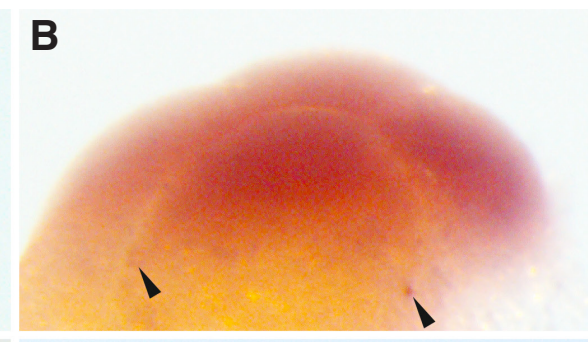

D

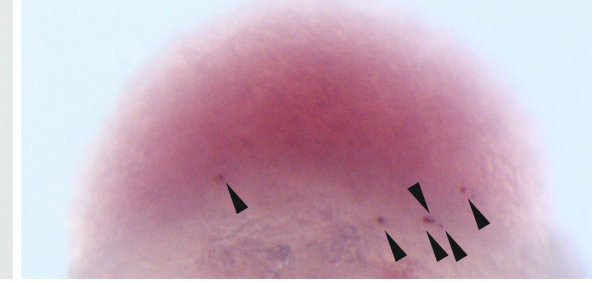

$\mathbf{F}$
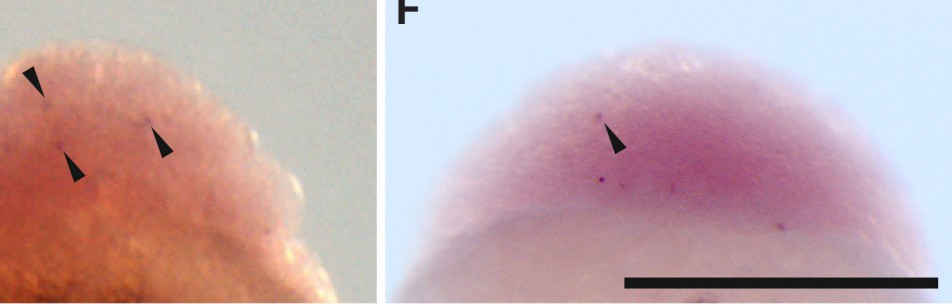

Fig. 2. Localization of vasa signal during cleavage and blastula stages. Vasa signals are (A) 2 cell strowheads and are located at the cleavage furrow during the cleavage period. at the cleavage furrow between the upper and lower blastomeres. (F) $1 \mathrm{k}$ cell stage take over the vasa signal at 16 cell stage. Scale bar denotes $500 \mu \mathrm{m}$.

formed (Supplementary Fig. S2 Y).

In order to analyze the embryonic body formation process more precisely, whole-mount in situ hybridization (WM-ISH) was performed using goosecoid ( $g s c$, a marker of the tip of invaginating cells; enclosed by black dotted line in Supplementary Fig. S6) and no tail (ntl, a marker of germ ring and forming embryonic body; enclosed by white dotted line in Supplementary Fig. S6). As epiboly proceeded from the $30 \%$ to the $90 \%$ epiboly stage, the region showing expression of $n t /$ moved towards the vegetal pole, while that of gsc stayed around the equatorial plane (Supplementary Fig. S6 A-D). After the $90 \%$ epiboly stage, the region of gsc expression moved towards the animal pole and was followed by that of $n t l$ expression, suggesting the occurrence of an extension movement (Supplementary Fig. S6 D,E). Taken together, the movement which form embryonic body was arrested during the 30 to $90 \%$ epiboly stage, after that dramatic conversion and extension movements occurred resulting in embryonic body formation.

\section{Formation of the digestive system}

At the 44-somite stage, a depression was present on the dorsal part of the yolk in the $1^{\text {st }}$ to $4^{\text {th }}$ somites region, indicating the formation of the intestinal bulb (Supplementary Fig. S3H). Subsequently, the intestinal bulb moved posteriorly and at $14 \mathrm{dpf}$ stage occupied the $11^{\text {th }}$ to $14^{\text {th }}$ somite region (Supplementary Fig. S4D). At this stage, the intestinal bulb and intestinal tract were located between the $11^{\text {th }}$ and $38^{\text {th }}$ somites, occupied 27 somites in length. From this stage, 
liver formation was observed in the ventral part of the intestinal bulb (Supplementary Fig. S4D"), and the intestinal bulb and liver extruded towards the intestinal tract.

In hatching stage embryos, the intestinal bulb and liver were located between the $11^{\text {th }}$ and $17^{\text {th }}$ somites, while the intestinal tract was located between the $18^{\text {th }}$ and $38^{\text {th }}$ somites. The length of the intestinal tract shrunk to 20 somites, although the intestinal bulb, liver and intestinal tract still occupied a total of 27 somites (Supplementary Fig. S4H). This suggests that the apparent shortening of the intestinal tract may result from enlargement of the intestinal bulb and liver.

\section{Origin of PGCs}

The origin of PGCs was analyzed by WM-ISH using the germ line marker gene vasa. From the 2-cell to 8-cell stages, vasa signals were detected at the cleavage furrow (arrowheads in Fig. 2 A-C). At the 16-cell stage, some embryos had signals between the upper and lower blastomeres (arrowheads in Fig. 2E). At the 1000 -cell (1k-cell) stage, the distribution pattern of vasa positive cells was similar to that at the cleavage period (arrowheads in Fig. 2D). Signals observed at the 16-cell stage were also inherited at the $1 \mathrm{k}$-cell stage (arrowhead in Fig. 2F). moved posteriorly. The distribution of PGCs became narrower as development advanced, and the cells located from the first somite to the tail bud region at the 12-somite stage (Fig. 3E, E'), from the $13^{\text {th }}$ to $24^{\text {th }}$ somite region at the 58-somite stage (Fig. 3 F,F'), from the $15^{\text {th }}$ to $24^{\text {th }}$ somite in the $12 \mathrm{dpf}$ stage (Fig. 3G, G') and from the $16^{\text {th }}$ to $24^{\text {th }}$ somite at the hatching stage (Fig. $3 \mathrm{H}$ ). In each embryo, PGCs were distributed at the same area after $12.0 \mathrm{dpf}$. In support of this result, PGCs in $14 \mathrm{dpf}$ embryos had a roundish shape (Supplementary Fig. S7). In zebrafish, non-motile PGCs show a similar spherical shape.

\section{Formation of the gonad at 3 days and 1 month post hatching}

At 3 days post hatching (dph), PGCs with GFP fluorescence were distributed between the $16^{\text {th }}$ and $24^{\text {th }}$ somite region forming a row on the dorsal side of endodermal organs, e.g. liver, pancreas, pyloric part of stomach and intestinal tract (Fig. 4 A',A"). A right-left asymmetry in distribution of PGCs was not observed. Histological analysis showed PGCs were present among the dorsal mesentery cells attached to the gut (Fig. $4 \mathrm{~B}, \mathrm{C}$ ) or on the dorsal mesentery (Fig. 4D). In the region where PGCs were distributed, the pyloric part of stomach (Fig. 4C) and the anterior part of the intestinal tract with villus structure on its surface could be seen (Fig. 4D).

\section{Migration route of PGCs}

PGCs were visualized using GFP-conjugated zebrafish nos3 3'UTR mRNA. PGCs could be distinguished by GFP staining after the $50 \%$ epiboly stage. Same to the 1k-cell stage (Fig. $2 \mathrm{D}, \mathrm{F}), \mathrm{PGCs}$ were clustered around the germ ring at the $50 \%$ epiboly stages (Fig. 3 A, A'). From the $50 \%$ to $90 \%$ epiboly stages, PGCs moved to the vegetal pole region (Fig. $3 \mathrm{~A}-\mathrm{C}$, $\left.A^{\prime}-C^{\prime}\right)$. As epiboly proceeded, the number of GFP positive cells increased but the distribution pattern remained similar. This indicated that PGCs were moved passively by somatic cell movements. From the $90 \%$ epiboly stage to the 12-somite stage, PGCs showed a dramatic mass movement to the lateral side of the forming embryonic body (Fig. 3 C-E, C'-E'). This movement was consistent with somatic cell movements that form the embryonic body. Consequently, PGCs were arranged in lines on both sides of the embryonic body, and then

Fig. 3. Migration route of primordial germ cells (PGCs) during gastrula, segmentation and hatching period. $P G C$ s are visualized by specific expression of GFP. A-H are side views and $A^{\prime}-G^{\prime}$ are dorsal views. (A, $\left.\mathbf{A}^{\prime}\right)$ 50\% epiboly stage. Distribution of PGCs is similar to that at the $1 \mathrm{k}$-cell sage (Fig. 2F) except for the number. (B,B') 70\% epiboly stage. (C,C') 90\% epiboly stage. (D,D') Embryonic body formation stage. (E,E') 12-somite stage. PGCs distribute from the $1^{\text {st }}$ to the tail bud region. $\left(\mathbf{F}, \mathbf{F}^{\prime}\right)$ 58-somite stage. PGCs distribute from $13^{\text {th }}$ to $24^{\text {th }}$ somite region. $\left(\mathbf{G}, \mathbf{G}^{\prime}\right) 12 \mathrm{dpf}$. PGCs distribute from the $15^{\text {th }}$ to $24^{\text {th }}$ somite region. $(\mathbf{H})$ Hatching stage embryo. PGCs distribute from the $16^{\text {th }}$ to $24^{\text {th }}$ somite region. Scale bars denote $500 \mu \mathrm{m}$.
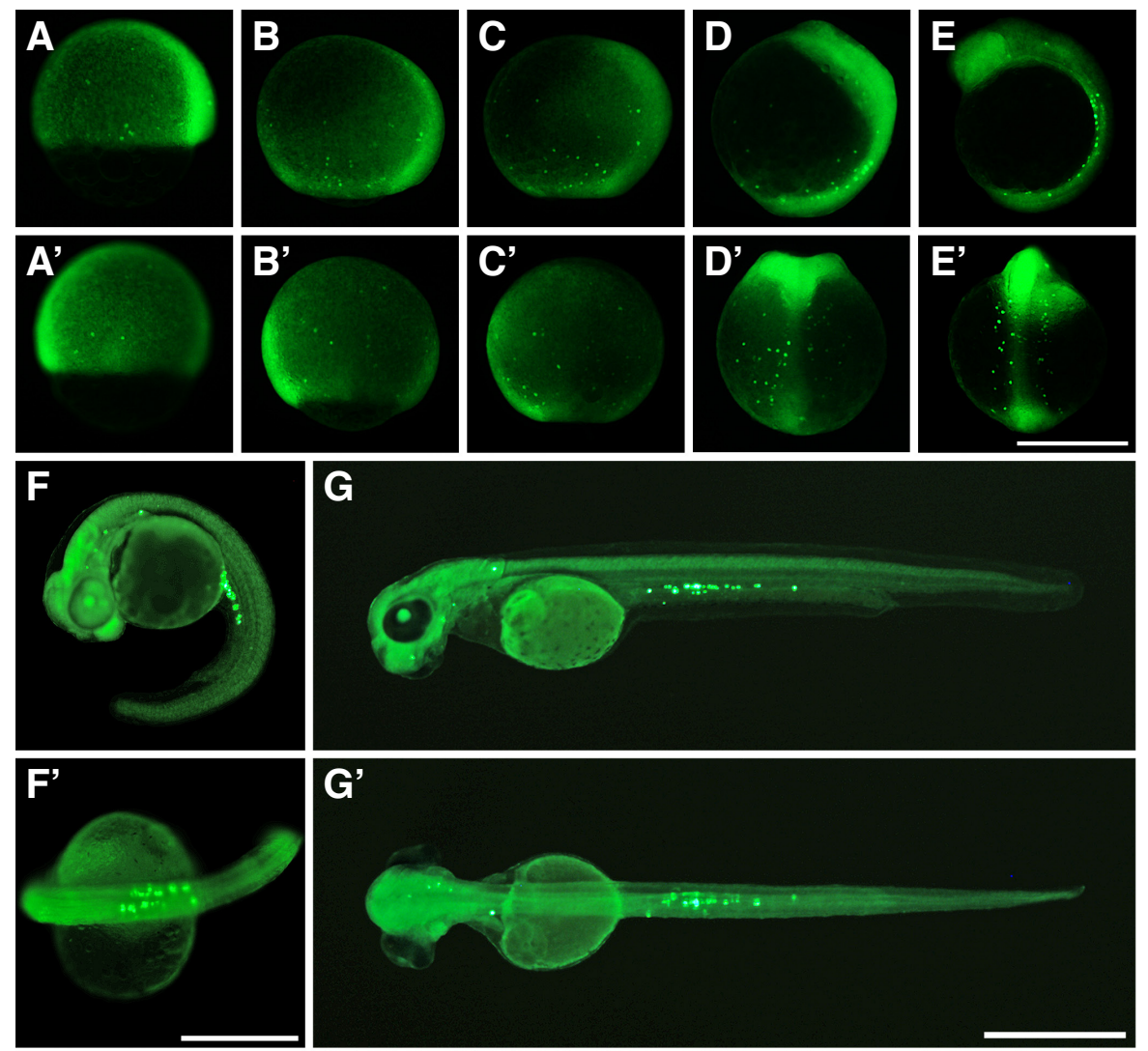

H

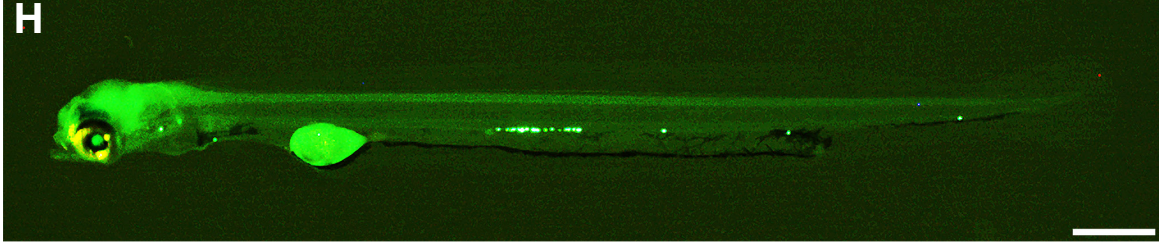


Fig. 4. Spatial localization of primordial germ cells (PGCs) in $\mathbf{3}$ dph larvae. (A) 3 dph larvae observed using transmitted light microscopy. Endodermal organs, e.g. liver, pyloric part of stomach and intestinal tract, are clearly observable in whole embryos. ( $\left.\mathbf{A}^{\prime}\right)$ Higher magnification of the region marked in the rectangle in A. The photograph is merged with the fluorescence image showing GFP positive cells (PGCS). PGCs distribute from the $16^{\text {th }}$ to $24^{\text {th }}$ somite region dorsal to the liver, pancreas, pyloric part of stomach and intestinal tract. (A") Dorsal view of $A^{\prime}$. PGCs' distribution shows no laterality. (B) Histological section cut approximately at the position marked as $B$ in $\left(A^{\prime}\right)$. PGCs are distributed among dorsalmesentery cells, which locate in the dorsal region of the body cavity. Around this region, the pancreas and posterior end of liver can be observed. (C) Histological section at the position marked as $C$ in $\left(A^{\prime}\right)$. PGCs are present among dorsal mesentery cells. Around this region, the pyloric part of the stomach and bile duct extending from the liver are observed. (D) Histological section at
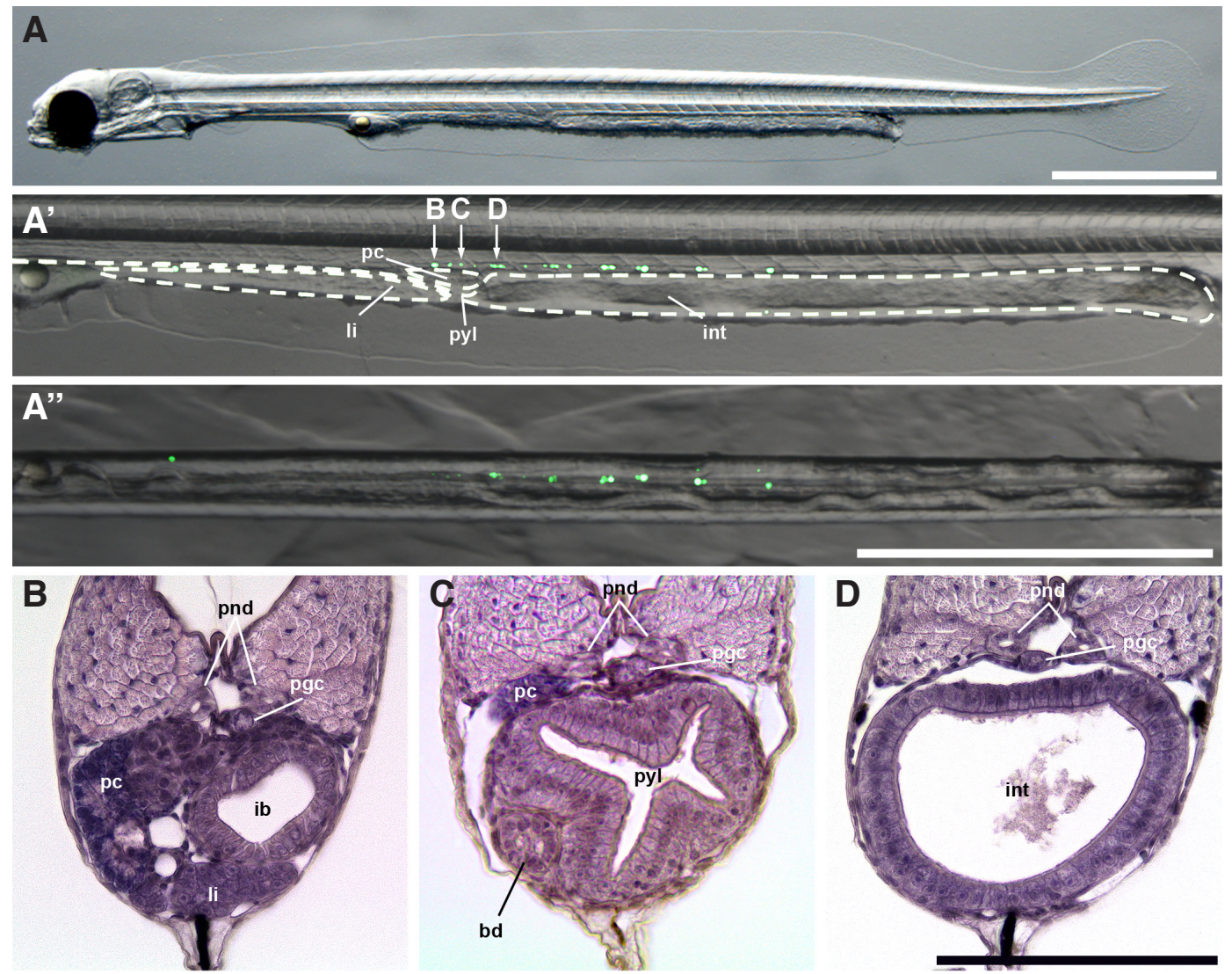

the position marked as D in ( $\left.A^{\prime}\right)$. PGCs are distribute on the dorsal mesentery. bd: bile duct, ib: intestinal bulb, int: intestinal tract, li: liver, pc: pancreas, pgc: primordial germ cell, pnd: pronephric duct, pyl: pyloric part of stomach. Scale bars in (A to $\left.A^{\prime \prime}\right)$ denote $1000 \mu \mathrm{m}$ and (B - D) denote100 $\mu \mathrm{m}$.

At 1 month post hatching ( $\mathrm{mph}$ ), the swim bladder was ventrally connected to the gut at the $19^{\text {th }}$ somite region (Fig. 5A' and $\mathrm{B}$ ) and this region contained no PGCs (Fig. 5B). The left gonad was observed at the $20^{\text {th }}$ somite region posterior to the middle part of the swim bladder (Fig. 5 D,E). Both sides of the gonad were observed in a space at the posterior end of the pancreas and swim bladder (Fig. 5F). PGCs were not detected in the more posterior area around $21^{\text {th }}$ to $24^{\text {th }}$ somite region (Fig. 5G) where they had been observed previously at the $3 \mathrm{dph}$ stage.

The number of PGCs in each $8 \mu \mathrm{m}$ thick histological section was counted on the right and left sides along the anteroposterior axis of each embryo (Fig. 6). On the right side, PGCs were present from the posterior end of the left gonad, and a mean of 8 PGCs was observed. On the left side, PGCs were present from the middle to posterior of the swim bladder, and a mean of 37.5 PGCs was observed. Thus, more PGCs were present in the left side compared to the right side, showing asymmetrical gonad formation (Fig. 6).

\section{Discussion}

Comparison of embryonic development in pond smelt and zebrafish showed little difference in the schedule of organ formation, although significant differences were observed in the positions of the intestinal bulb and liver. In both species, the intestinal bulb budded in the $1^{\text {st }}$ to $3^{\text {rd }}$ somite region, the dorsal center of the yolk, while the digestive organs subsequently differentiated later in a different manner in each species. In zebrafish, the intestinal bulb remains in the $1^{\text {st }}$ to $4^{\text {th }}$ somite region and the liver forms in the $1^{\text {st }}$ somite region, anterior to the intestinal bulb (Field et al., 2003). In contrast, in the pond smelt, the intestinal bulb moved to the $11^{\text {th }}$ to $14^{\text {th }}$ somite region, around the posterior edge of the yolk, and the liver was formed at the ventral part of intestinal bulb. After this stage the intestinal bulb and liver grew and occupied the $11^{\text {th }}$ to $17^{\text {th }}$ somite region. The digestive tract, intestinal bulb and intestinal tract consistently occupied 27 somites during differentiation. These results in pond smelt indicate that the liver and intestinal bulb extended and pushed the intestinal tract in a posterior direction. Despite the essential functions of the digestive system, little is known about anteroposterior axis patterning mechanisms. The differentiation of the digestive system from the gut has been investigated for the pancreas (Hick et at., 2009) and the liver (Field et al., 2003) in zebrafish. However, zebrafish is not a suitable model to analyze anteroposterior axis formation because the fish lack a stomach and have unclear boundaries in the gut. In this study, we were able to characterize the anteroposterior axis of the digestive organs in pond smelt. Therefore, given this characterization and other features, such as a transparent body, we suggest pond smelt is a good alternative model for studying pattern formation of the digestive system.

In pond smelt, PGCs were clearly visualized using GFP nos3 3. UTR mRNA, as is the case in other fish species (Saito et al., 2006, 2011, 2014; Nagasawa et al., 2013; Goto et al., 2015). However, PGCs were detected earlier in embryonic development in pond smelt than zebrafish and other teleost species, because of 
Fig. 5. Formation of gonad in $\mathbf{1} \mathbf{~ m p h}$ larvae. (A) Whole image of $1 \mathrm{mph}$ larvae. The swim bladder can be seen. $\left(\mathbf{A}^{\prime}\right)$ Higher magnification images of rectangle in (A). Green bar at 20 somite region shows the area of distribution area of the gonad estimated from the histological sections. (B) Histological section at the position marked as $B$ in $\left(A^{\prime}\right)$. Dorsal part of pyloric region of gut protrudes and swim bladder is formed. Swim bladder has two-layered structure: inner endodermal cells derived from gut and outer mesodermal cells derived from dorsal mesentery cells. (C) Histological section at the position marked as $C$ in $\left(A^{\prime}\right)$. Swim bladder is separate from the pyloric region of gut. (D) Histological section at the position marked as $D$ in $\left(A^{\prime}\right)$. Left gonad is observable as a thickening of outer cells of the swim bladder. (E) Histological section at the position marked as $E$ in $\left(A^{\prime}\right)$. Left gonad with a PGC is present. (F) Histological section at the position marked as $F$ in $\left(A^{\prime}\right)$. Posterior end of the swim bladder at which the pancreas is small. Right and left-gonad have PGCs covered with somatic cells. (G) Histological section at the position markedas $G$ in $\left(A^{\prime}\right)$. Posterior of the pancreas. At the $21^{\text {st }}$ to $24^{\text {th }}$ somite region, where PGCs are detected at the hatching stage, the gonad shows no differentiation. int: intestinal tract, l-gd: left-gonad, li: liver pc: pancreas, pnd: pronephric duct, pyl: pyloric part of stomach, r-gd: right-gonad, sb: swim bladder. Scale bars in $\left(A, A^{\prime}\right)$ denote $1000 \mu \mathrm{m}$ and in (B-G) denotes $100 \mu \mathrm{m}$.
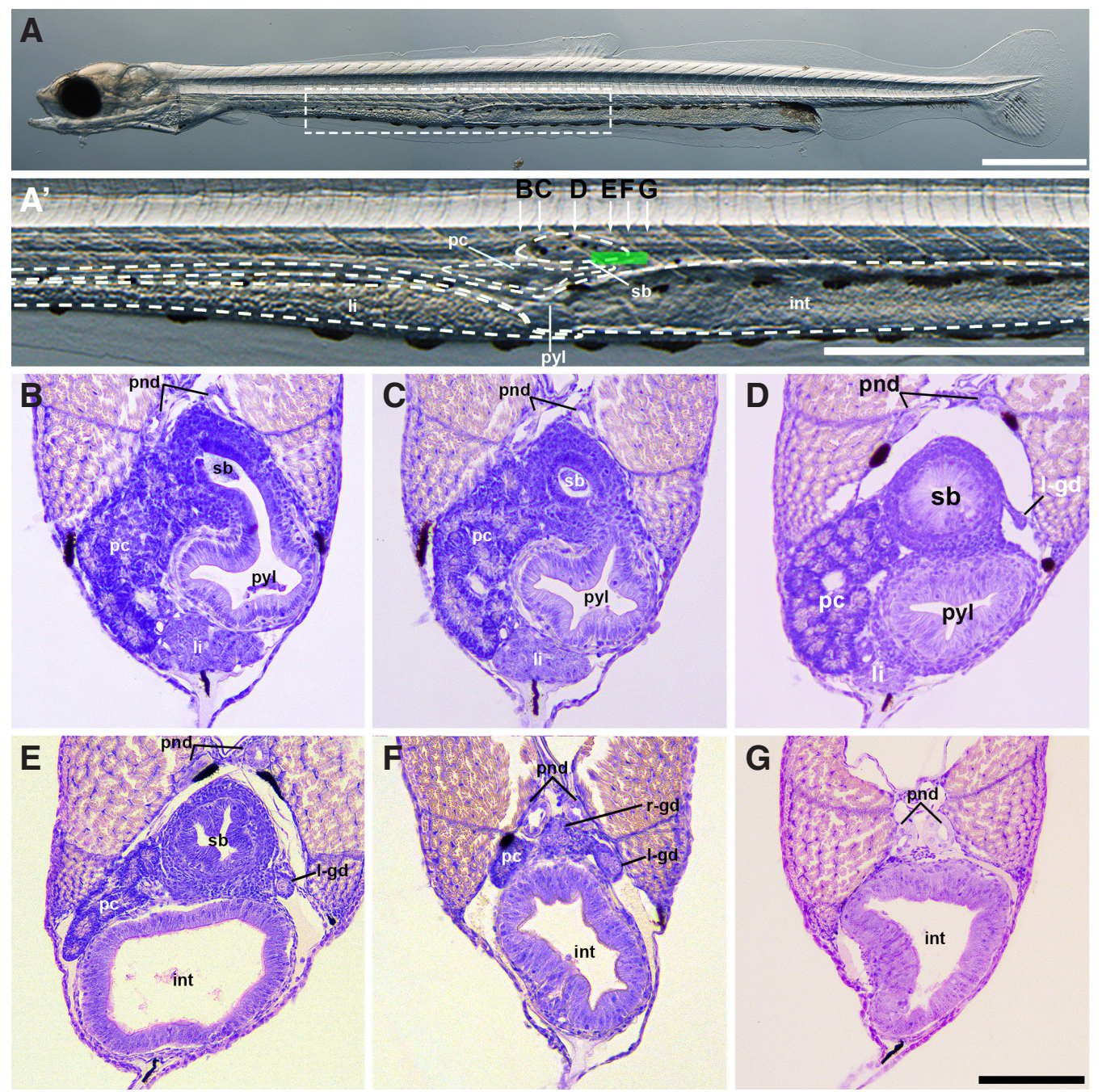

a brighter GFP signal compared to these other species. In PGCs, the DEAD END protein, which is included in the germ plasm, binds to the nos33'UTR sequence mRNA and protects it from digestion by the CCR4-NOT1 complex in the course of post-transcriptional regulation by miRNA (Kedde et al., 2007; Chekulaeva and Filipowicz, 2009). In somatic cells, which obviously lack germ plasm, the mRNA is digested due to the absence of DEAD END protein and therefore the cells show low levels of GFP fluorescence. Thus, GFP fluorescence can be used to distinguish PGCs and somatic cells. The CCR4-NOT1 complex, which digests mRNA, presumably has a different optimum temperature in zebrafish and pond smelt as enzymes usually have their highest activity at the temperature of the species' normal environment. Therefore, it is possible that the CCR4-NOT1 complex shows the same level of activity at $28.5^{\circ} \mathrm{C}$ in zebrafish as at $10^{\circ} \mathrm{C}$ in pond smelt. Therefore, we hypothesize that much of the GFP-nos 3'UTR mRNA in somatic cells is digested in the longer embryonic development of pond smelt, enabling greater GFP fluorescence in PGCs.

In pond smelt, vasa signals were identified at the cleavage furrow indicating that PGCs are derived from cells that inherit maternally-synthesized germ plasm, in a similar manner as other teleosts (Fig. 1). During the late blastula to gastrula stage, PGCs migrated along with somatic cells from the germ ring region and were widely distributed on the lateral side of the embryonic body. This migratory behavior is termed pattern 1 in Fig. 1 and is similar to that in goldfish, ukigori, turbot and other species. During the segmentation period, PGCs migrated posteriorly and were located in a 6 somite wide region posterior to the $16^{\text {th }}$ somite from $12 \mathrm{dpf}$ to the hatching stage. At the $14 \mathrm{dpf}$ stage, PGCs had a roundish shape (Supplementary Fig. S7). In zebrafish, PGCs extend pseudopodia during migration and thereafter have a roundish shape after localization at genital ridge (Blaser et al., 2005). Our observations suggest that in pond smelt, PGCs have no motility after the pharyngula period. However, PGCs distributed from the $16^{\text {th }}$ to $24^{\text {th }}$ somites region at $3 \mathrm{dph}$ moved to the $20^{\text {th }}$ somite region at $1 \mathrm{mpf}$. In medaka, somatic cells which locate posterior region of lateral plate mesoderm release Stromal cell-Derived Factor 1a (SDF-1a) and PGCs have its receptor C-X-C chemokine receptor type 4 (CXCR4). PGCs autonomously migrate to SDF-1a expression domain and are covered by somatic gonadal precursor cells. They then move anteriorly and medially to the embryonic body in a passive manner mediated by somatic cell movements. Consequently, one gonad is formed with right and left PGCs and somatic cells (Nakamura et al., 2006). Similar to this mechanism, in pond smelt, our results indicate that PGCs are surrounded by somatic dorsal mesentery cells and move passively to the $20^{\text {th }}$ 
somite region as a result of somatic cell movements, and then differentiate into the gonad. PGC migration in pond smelt is passive during gastrulation, autonomous during segmentation, and passive after $14 \mathrm{dpf}$.

Right-left gonadal asymmetry is known in osmerid fish, including pond smelt (Supplementary Fig. S1). The left gonad is larger in mature fish. In this study, PGCs show biased distribution to the left sided gonad at $1 \mathrm{mph}$. PGCs were symmetrically distributed before $12 \mathrm{dpf}$, and were central located at $3 \mathrm{dph}$. After hatching, the pancreas differentiated and filled the right side of the abdominal cavity, leaving a small space in the left side. Therefore, we suggest that right-left gonadal asymmetry was generated by redistribution of PGCs that had accumulated by the dorsal mesentery cells during gonadal formation with somatic cells and/or pancreas differentiation. In zebrafish, the direction of liver budding and intestinal bulb looping are correlated; however, in the Ntl mutant they become independent, indicating that right-left behavior of these tissues can be regulated separately (Field et al., 2003). Although the right-left differentiation of the pancreas and PGCs seems to be correlated in pond smelt, it remains possible that they are regulated by different mechanisms. Further investigations will be necessary to determine whether this is the case.

In addition to dextrosinistral laterality, the mechanisms for gonadal differentiation along the anteroposterior axis remain unknown. In pond smelt, PGCs were present in the $15^{\text {th }}$ to $24^{\text {th }}$ somites region at $12 \mathrm{dpf}$ embryos and moved to the $16^{\text {th }}$ to $24^{\text {th }}$

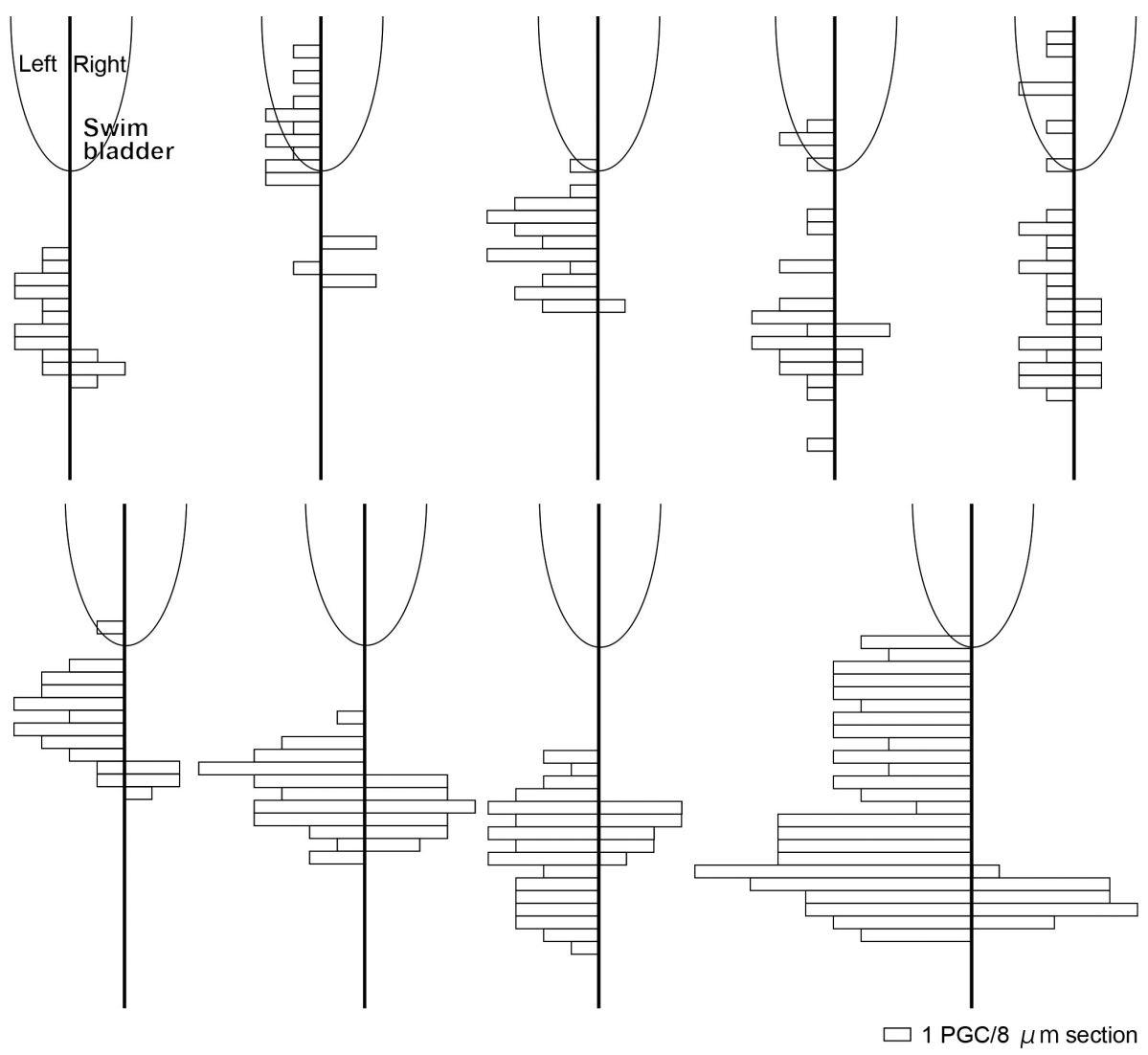

Fig. 6. Right-left asymmetry of primordial germ cell (PGC) distribution at the $1 \mathbf{~ m p h}$ stage. Number of PGCs in the right and left gonads (indicated on the right and left of the vertical line) in $8 \mu \mathrm{m}$ serial sections from 9 individuals. The partial ovoid indicates the posterior part of the swim bladder. somites region at the $3 \mathrm{dph}$ stage, just posterior to intestinal bulb; they finally located around the $20^{\text {th }}$ somite region as the gonad. The final position is considerably posterior to that of zebrafish $\left(5^{\text {th }}\right.$ to $7^{\text {th }}$ somite region; Yoon et al., 1997) and medaka (12 to $13^{\text {th }}$ somite region; Sasado et al., 2004). This difference is a consequence of the formation of anterior organs, namely esophagus and stomach, in pond smelt but not zebrafish and medaka. However, in all three species, the gonad differentiates just posterior to where the liver, pancreas and intestinal bulb differentiate. The intestinal bulb, in which PGCs are commonly distributed in its posterior region, first differentiates in a similar region in pond smelt $\left(1^{\text {st }}\right.$ to $4^{\text {th }}$ somite region), zebrafish ( $1^{\text {st }}$ to $4^{\text {th }}$ somite region; Field et al., 2003) and medaka ( $1^{\text {st }}$ to $3^{\text {rd }}$ somite region; Iwamatsu, 2004). It is possible that the positions of liver, pancreas and intestinal bulb are prepatterned by a common mechanism in these three species. In addition to this, the position of the gonads might be determined by the same common mechanism as these endodermal organs. In the mouse, mesenchymal cells release SDF-1 and induce epithelial bud branching from the gut which have its receptor; CXCR4 and consequently the structure of the pancreas is formed (Hick et al., 2009). As indicated above, migration of PGCs is regulated by CXCR4 and SDF-1 system commonly to branching of the pancreas.

In this study we showed that the transparent body of pond smelt during embryonic development can be exploited to investigate organogenesis in this species. We also showed that molecular biological techniques developed in other fish species can also be applied to pond smelt. These features and the biology of pond smelt make them a good model system for investigating organogenesis and gonad formation, in particular with regard to the formation of the dextrosinistral and anteroposterior axes in teleosts.

\section{Materials and Methods}

\section{Ethics}

This study was carried out in accordance with the Guide for the Care and Use of Laboratory Animals in Hokkaido University and the Field Science Center for Northern Biosphere, Hokkaido University (Approval number 22-1).

\section{Embryo preparation}

Mature pond smelt running up river from the sea for spawning were captured by a spoon net from the Ryukei River, Hokuto, Hokkaido, Japan at midnight at the end of April. Eggs were collected onto vinylidene chloride film (Saran Wrap: Asahi Kasei Co., Ltd., Tokyo, Japan) and milt into a microcapillary tube (Terumo Co., Ltd., Tokyo, Japan) by gently pressing on the abdomen. Fertilization was carried out by dry method. About 300 eggs were scattered in a $90 \mathrm{~mm}$ diameter petri dish filled with $50 \mathrm{ml}$ tap water. Fertilized eggs were washed with tap water three times within $1 \mathrm{~min}$. Dechorionation was carried out by trypsin under high $\mathrm{pH}$ conditions optimized for rainbow smelt (Takahashi et al., 2016) with slight modifications. Fertilized eggs were treated with $15 \mathrm{ml}$ of smelt's Ringer's solution (SRS: $128 \mathrm{mM} \mathrm{NaCl}, 2.8 \mathrm{mM}$ $\mathrm{KCl}, 2.7 \mathrm{mM} \mathrm{CaCl}_{2}$ ) containing $0.1 \%$ trypsin and $100 \mu \mathrm{l}$ of $1 \mathrm{~N} \mathrm{NaOH}$ for 1 min followed by adding 
$30 \mathrm{ml}$ of SRS containing $0.1 \%$ trypsin without $\mathrm{NaOH}$. After $3 \mathrm{~h}$ treatment, almost all of the eggs were dechorionated. Dechorionated embryos were transferred to an agar-coated petri dish filled with SRS containing 1.6\% albumin. After $3 \mathrm{~h}$ incubation, embryos were cultured in SRS without albumen until embryonic body formation stage; they were then transferred to tap water. All procedures were performed at $10^{\circ} \mathrm{C}$.

\section{Observation and photography of whole embryos}

Petri dishes coated with $5 \mathrm{~mm}$ agar were used for observation. Photography was carried out using a fluorescence stereomicroscope (Leica MZ16F, Leica Microsystems GmbH, Wetzlar, Germany) with attached digital camera (Leica DFC300 FX, Leica Microsystems GmbH). Higher magnification observations and photography were carried out using an inverted microscope (Leica DMI6000 B, Leica Microsystems GmbH) with attached digital camera (Leica DFC350 FX).

\section{Establishment of basic outline of pond smelt embryonic development}

Normal embryonic development of pond smelt at $10^{\circ} \mathrm{C}$ was investigated using dechorionated embryos. Five embryos were selected and transferred to a petri dish coated with agar. Fresh embryos were selected at every observation period. In order to investigate the timing of Mid-blastula transition (MBT), nuclei were stained with $5 \mu \mathrm{g} / \mathrm{ml}$ 4'-6-diaminido-2-phenylindole (DAPI) dissolved in $10 \mathrm{mM}$ Tris-HCl (pH 7.4), $5 \mathrm{mM}$ EDTA, and $0.15 \mathrm{M}$ $\mathrm{NaCl}$ for $30 \mathrm{~min}$. Approximately 50 dechorionated embryos from the 512 to $2 \mathrm{k}$ cell stage were fixed every $1.25 \mathrm{~h}$ (half of 1 cell cycle) in $2 \%$ glutaraldehyde in phosphate-buffered saline (PBS) overnight. Fixed embryos were washed with PBS and stored at $4^{\circ} \mathrm{C}$ until analysis.

WM-ISH was used to analyze embryonic body formation. Two probes were selected: goosecoid ( $g s c)$, which is a marker of the tip of invaginating cells; and, no tail (ntl), which is a marker for the germ ring and forming embryonic body. The gsc RNA probe was labeled with digoxigenin and was stained deep purple with NBT and BCIP. The $n t /$ RNA probe was labeled with FITC and stained brown with DAB. Approximately 50 dechorionated embryos were fixed in $4 \%$ paraformaldehyde in PBS overnight. Fixed embryos were stored and dehydrated with methanol at $-20^{\circ} \mathrm{C}$. Construction of RNA probes and their application in WM-ISH were as described by Fujimoto et al., (2006).

\section{Investigation of origin of PGCs with WM-ISH}

The origin of the PGCs was investigated using vasa (Yoon et al., 1997) as the germ plasm and germ line cell marker. The RNA probe was labeled with digoxigenin and stained deep purple with NBT and BCIP.

\section{Visualization of PGCs}

GFP nos3 3' UTR mRNA was prepared as described by Saito et al., (2006) and was injected into 1-cell embryos and detected as described.

\section{Histology}

Hatched larvae were fixed in Bouin's fixative for $3 \mathrm{~h}$. Fixed larvae were washed with $80 \%$ ethanol, dehydrated through a butyl alcohol series, and subsequently embedded in a paraffin block. Serial transverse sections ( $8 \mu \mathrm{m}$ thick) were cut and stained with hematoxylin and eosin according to standard procedures. Observation and photography were carried out with a Leica DM2500 microscope (Leica Microsystems $\mathrm{GmbH}$ ) with attached digital camera (Leica DFC295 FX). PGCs were confirmed by their histological characteristics, such as a round shape, relatively large size, large nucleus and clear nuclear membrane (Nagai et al., 2001).

\section{Acknowledgements}

We would like to express our gratitude to Dr. Kunio Inoue in Kobe University for kindly donating the gfp-zf nos3 3'UTR mRNA construct. We also would like to express our gratitude to the members of the Nanae Fresh-water Laboratory, Field Science Center for Northern Biosphere, Hokkaido University for assistance with obtaining experimental fish, conducting the experiments, and discussing the results. This study was supported by grants from the Bio-oriented Technology Research Advancement Institution (BRAIN) of Japan.

\section{References}

BETANCUR-R R, BROUGHTON R E, WILEY E O, CARPENTER K, LÓPEZ J A, LI C, HOLCROFT N I, ARCILA D, SANCIANGCO M, CURETON II J C, ZHANG F, BUSERT, CAMPBELLMA, BALLESTEROS JA, ROA-VARONA, WILLIS S, BORDEN W C, ROWLEY T, RENEAU P C, HOUGH D J, LU G, GRANDE T, ARRATIA G, ORTI G (2013). The tree of life and a new classification of bony fishes. PLOS Curr. Tree Life doi: 10.1371/currents.tol.53ba26640df0ccaee75bb165c8c26288.

BLASER H, EISENBEISS S, NEUMANN M, REICHMAN-F M, THISSE B, THISSE C RAZ E (2005). Transition from non-motile behavior to directed migration during early PGC development in zebrafish. J Cell Sci 118: 4027-4038.

CHEKULAEVA M, FILIPOWICZ W (2009). Mechanisms of miRNA-mediated posttranscriptional regulation in animal cells. Curr Opin Cell Biol 21: 452-460.

EIGENMANN C H (1891). On the precocious segregation of the sex-cells in Micrometrus aggregatus, gibbons. $J$ Morphol 5: 481-492.

EXTAVOUR C G, AKAM M (2003). Mechanisms of germ cell specification across the metazoans: epigenesist and preformation. Development 130: 5869-5884.

FIELD HA, OBEREA, ROESERT, STAINIERD YR (2003). Formation of the digestive system in zebrafish. I. liver morphogenesis. Dev Biol 253: 279-290.

FUJIMOTO T, KATAOKA T, SAKAO S, SAITO T, YAMAHA E, ARAI K (2006). Developmental stages and germ cell lineage of the loach (Misgurnus anguillicaudatus). Zool Sci 23: 977-989.

FUJIMOTO T, NISHIMURA T, GOTO-K R, KAWAKAMI Y, YAMAHA E, ARAI K (2010). Sexual dimorphism of gonadal structure and gene expression in germ cell-deficient loach, a teleost fish. Proc. Natl. Acad. Sci. USA 107: 17211-17216.

GOTOR, SAITOT, KAWAKAMIY, KITAUCHIT, TAKAGIM, TODOT, ARAIK, YAMAHA $E$ (2015). Visualization of primordial germ cells in the fertilized pelagic eggs of the barfin flounder Verasper moseri. Int J Dev Biol 59: 465-470.

GOTO R, SAITO T, TAKEDA T, FUJIMOTO T, TAKAGI M, ARAI K, YAMAHAE (2012). Germ cells are not the primary factor for sexual fate determination in goldfish. Dev Biol 370: 98-109.

HICKA C, EYLL J M V, CORDIS, FOREZ C, PASSANTE L, KOHARAH, NAGASAWA T, VANDERHAEGHEN P, COURTOY P J, ROUSSEAU G G, LEMAIGRE F P, PIERREUX C E (2009). Mechanism of primitive duct formation in the pancreas and submandibular glands: a role for SDF-1. BMC Dev Biol 9: 66.

IWAMATSU T (2004). Stages of normal development in the medaka Oryzias latipes. Mech Dev 121: 605-618.

KEDDE M, STRASSER M J, BOLDAJIPOUR B, VRIELINK J A F O, SLANCHEV K SAGE C L, NAGEL R, VOORHOEVE P M, DUIJSE J V, ØROM U A, LUND A H, PERRAKIS A, RAZ E, AGAMI R (2007). RNA-binding protein Dnd1 inhibits microRNA access to target mRNA. Cell 131: 1273-1286.

KIMMEL C B, BALLARD W W, KIMMEL S R, ULLMANN B, SCHILLING T F (1995) Stages of embryonic development of the zebrafish. Dev Dyn 203: 253-310.

LIN F, XU S, MA D, XIAO Z, ZHAO C, XIAO Y, CHI L, LIU Q, LI J (2012). Germ line specific expression of a vasa homologue gene in turbot (Scophthalmus maximus): evidence for vasa localization at cleavage furrows in euteleostei. Mol Reprod Dev 79: 803-813.

MOLYNEAUX K, WYLIE C (2004). Primordial germ cell migration. Int J Dev Biol 48: 537-543.

NAGAI T, YAMAHA E, ARIA K (2001). Histological differentiation of primordial germ cells in zebrafish. Zool Sci 18: 215-223.

NAGASAWA K, FERNANDES J M O, YOSHIZAKI G, MIWA M, BABIAK I (2013). Identification and migration of primordial germ cells in Atlantic salmon, Salmo salar: characterization of vasa, dead end, and lymphocyte antigen 75 genes. Mol Reprod Dev 80: 118-131.

NAKAMURA S, KOBAYASHI D, AOKI Y, YOKOI H, EBE Y, WITTBRODT J, TANAKA $M$ (2006). Identification and lineage tracing of two populations of somatic gonadal precursors in medaka embryos. Dev Biol 295: 678-688.

NAKATANI M, MIYA M, MABUCHI K, SAITOH K, NISHIDA M (2011). Evolutionary history of Otophysi (Teleostei), a major clade of the modern freshwater fishes: Pangaean origin and Mesozoic radiation. BMC Evol Biol 11: 177.

OTANI S, MAEGAWA S, INOUE K, ARAI K, YAMAHAE (2002). The germ cell lineage 
identified by vas-mRNAduring the embryogenesis in goldfish. Zool Sci19:519-526.

PRESSLAUER C, NAGASAWA K, FERNANDES J M, BABIAK I (2012). Expression of vasa and nanos 3 during primordial germ cell formation and migration in Atlantic cod (Gadus morhua L.). Theriogenology 78: 1262-1277.

SAITO T, FUJIMOTO T, MAEGAWA S, INOUE K, TANAKA M, ARAI K, YAMAHA E (2006). Visualization of primordial germ cells in vivo using GFP-nos1 3'UTR mRNA. Int J Dev Biol 50: 691-699.

SAITO T, GOTO-K R, KAWAKAMI Y, NOMURA K, TANAKA H, ADACHI S, ARAI K, YAMAHAE (2011). The mechanism for primordial germ-cell migration is conserved between Japanese eel and zebrafish. PLoS ONE 6: e24460.

SAITO T, OTANI S, FUJIMOTO T, SUZUKI T, NAKATSUJI T, ARIA K, YAMAHA E (2004). The germ line lineage in ukigori, Gymnogobius species (Teleostei: Gobiidae) during embryonic development. Int J Dev Biol 48: 1079-1085.

SAITO T, PŠENIČKA M, GOTO R, ADACHI S, INOUE K, ARAI K, YAMAHAE (2014).
The origin and migration of primordial germ cells in sturgeons. PLOSONE9: e86861. SASADO T, MORINAGAC, NIWAK, SHINOMIYAA, YASUOKAA, SUWAH, HIROSE Y, YODA H, HENRICH T, DEGUCHI T, IWANAMI N, WATANABE T, KUNIMATSU $S$, OSAKADA M, OKAMOTO Y, KOTA Y, YAMANAKA T, TANAKAM, KONDOH H, FURUTANI-S M (2004). Mutations affecting early distribution of primordial germ cells in Medaka (Oryzias laties) embryo. Mech Dev 121: 817-828.

TAKAHASHIE, KAWAKAMIY, ARIAK, YAMAHAE (2016). Dechorionation of fertilized eggs and embryonic development in arctic rainbow smelt Osmerus eperlanus mordax. Fish Sci 82: 639-652.

YAMADA J (1963). The normal developmental stages of the pond smelt, Hypomesus olidus (pallas). Bull Fac Fish Hokkaido Univ 14:121-126

YOON C, KAWAKAMI K, HOPKINS N (1997). Zebrafish vasa homologue RNA is localized to the cleavage planes of 2- and 4-cell-stage embryos and is expressed in the primordial germ cells. Development 124: 3157-3165. 


\section{Further Related Reading, published previously in the Int. J. Dev. Biol.}

Visualization of primordial germ cells in the fertilized pelagic eggs of the barfin flounder Verasper moseri Rie Goto, Taiju Saito, Yutaka Kawakami, Tomoe Kitauchi, Misae Takagi, Takashi Todo, Katsutoshi Arai, Etsuro Yamaha Int. J. Dev. Biol. (2015) 59: 465-470 http://www.ijdb.ehu.es/web/paper/150008rg

Evolutionary trend for metamery reduction and gonad shortening in Anurans revealed by comparison of gonad development Rafal P. Piprek, Anna Pecio, Malgorzata Kloc, Jacek Z. Kubiak and Jacek M. Szymura Int. J. Dev. Biol. (2014) 58: 929-934

http://dx.doi.org/10.1387/ijdb.140155rp

The problem of the origin of primordial germ cells (PGCs) in vertebrates: historical review and a possible solution

Giovanni Pilato, Vera D’Urso, Fabio Viglianisi, Francesca Sammartano, Giorgio Sabella and Oscar Lisi

Int. J. Dev. Biol. (2013) 57: 809-819

http://dx.doi.org/10.1387/ijdb.120261gp

Visualization of primordial germ cells in vivo using GFP-nos1 3'UTR mRNA

Taiju Saito, Takafumi Fujimoto, Shingo Maegawa, Kunio Inoue, Minoru Tanaka, Katsutoshi Arai and Etsuro Yamaha

Int. J. Dev. Biol. (2006) 50: 691-700

http://www.ijdb.ehu.es/web/paper/062143ts

\section{Primordial germ cell migration}

Kathleen Molyneaux and Christopher Wylie

Int. J. Dev. Biol. (2004) 48: 537-543

http://dx.doi.org/10.1387/ijdb.041833km

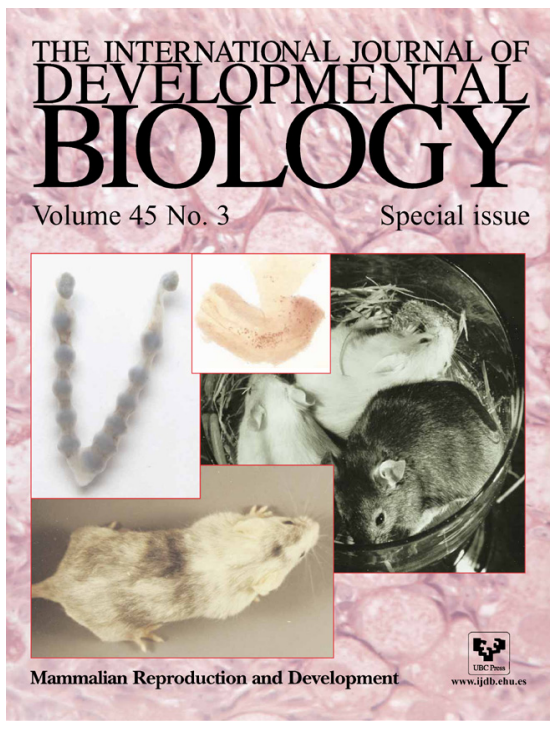

5 yr ISI Impact Factor $(2013)=2.879$
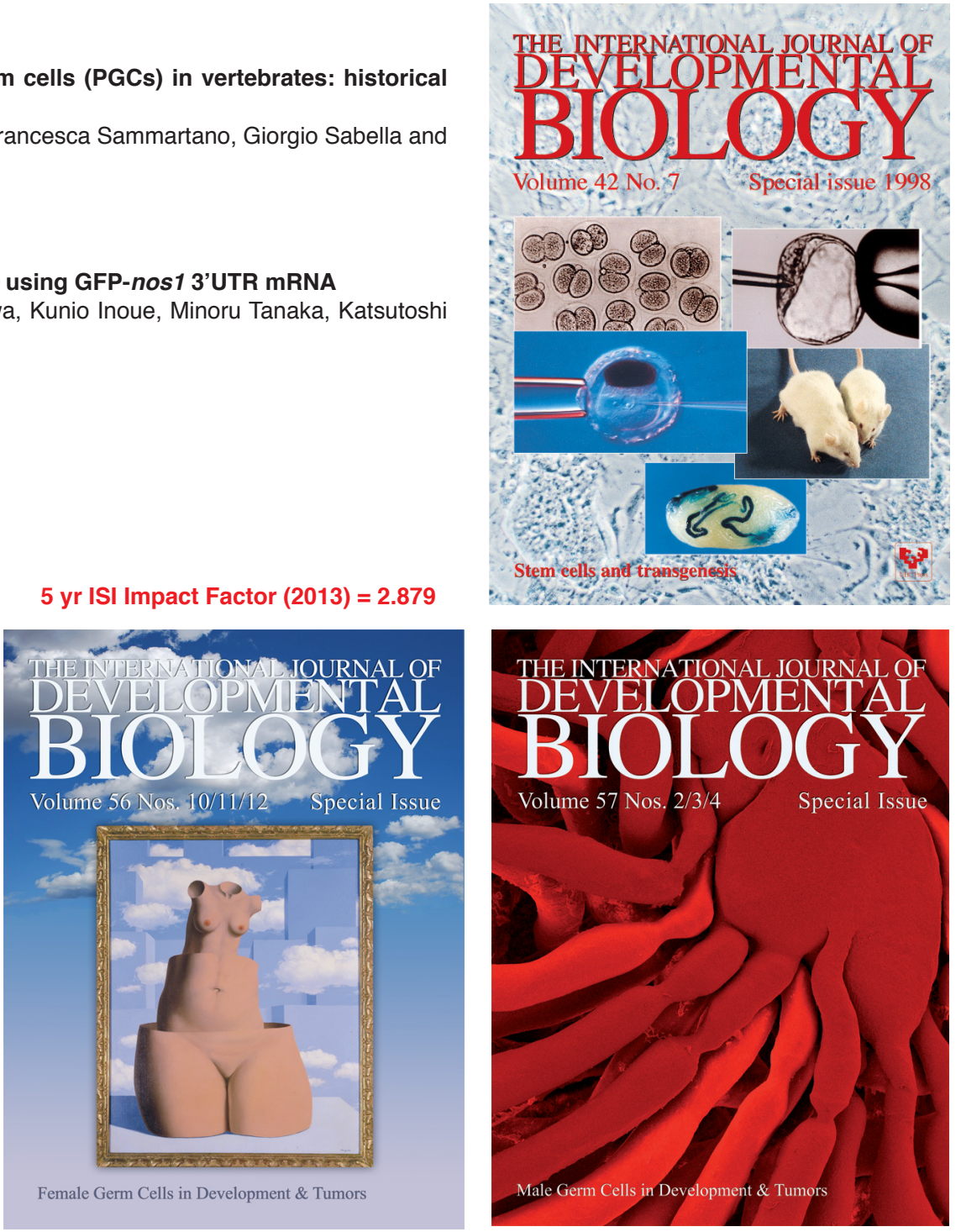